\title{
Wyoming physics faculty faces closure
}

[WASHINGTON] The University of Wyoming is considering closing its physics and astronomy department, a move that would make it the only state-run university in the United States not to award degrees in physics.

The plan is still in draft form and is not scheduled to go to the university's board of trustees for approval until July. But physics department chairman Paul Johnson acknowledges that his programme, which has seen a heavy fall in student numbers over the past few years, is facing a "severe threat".

A five-year academic plan drafted by the university administration calls for the closure of the masters and $\mathrm{PhD}$ programmes in physics and astronomy, and for the university's Wyoming Infrared Observatory (WIRO) to be sold or leased. The observatory's 2.3-metre infrared telescope is the third largest in the country.

The plan recommends that consideration be given to scrapping the bachelors degree programme and offering physics courses only as a 'service function' to other departments, such as engineering and geology. The philosophy department and some language programmes are also targeted for closure.

According to the plan, "numerous external reviews, including the most recent WIRO review, have questioned the [economic] sustainability of the physics/astrophysics program". The number of physics majors has dropped from 40 in 1993 to 25 today, and the

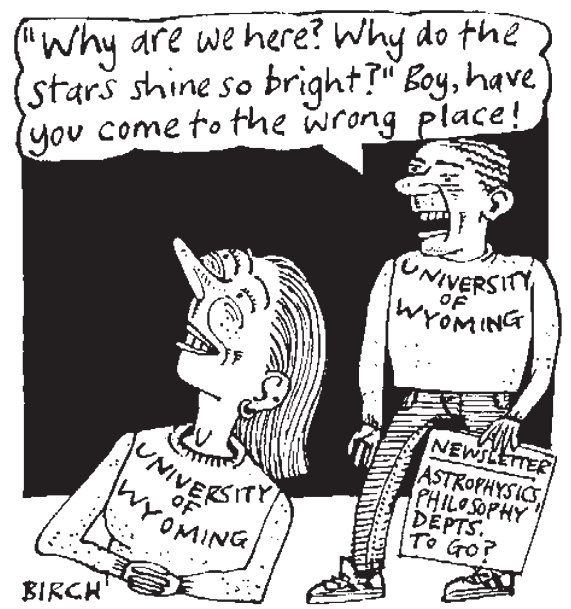

number of faculty members is down from 17 two years ago to 13 , with only five expected to remain after September.

A recent outside review of WIRO identified deficiencies including infighting among the astronomy faculty members. Although acknowledging past problems, Johnson says the move to eradicate physics reflects a "new climate in academia" focused on cost-benefit calculations. "It flabbergasts me that something at the core of science" could be dropped from the university, he says.

The WIRO review pointed out management flaws and a need for more modern instruments, but it concluded that the observatory is an "important and competitive facility... which has the potential to excel in certain key scientific niches".

Johnson says he would like to see the observatory run by a consortium of universities. The observatory is negotiating with Denver University in Colorado and other institutions.

Harley Thronson, who heads NASA's Origins programme to study evolution in the Universe, was a member of the faculty at Wyoming until the mid-1990s. He says the department, although small, has produced independent-minded scientists who have risen to "some of the most senior positions in the astronomical community".

James Madison University in Harrisonburg, Virginia, drew national attention in 1995 when it proposed - but later shelved - a plan to shut its physics department. Patrick Mulvey, who tracks data on university degree programmes for the American Institute of Physics in Washington, says he has noticed no trend in the number of physics departments closing down. In a typical year, he says, one or two colleges eliminate or scale down their physics programmes while another one or two expand.

But if the plan is approved, Wyoming would become the only state without a college offering physics degrees. That would make it a scientific backwater, says Johnson. Thronson agrees: Wyoming would lose its influence in astronomy at a time when the field is enjoying a golden era, he says.

Tony Reichhardt

\section{Geological problems drive up cost of nuclear waste dump in Japan}

[токуо] The Japanese government may have to revise its disposal programme for radioactive waste, following a report from the Ministry of International Trade and Industry (MITI) pointing out the expense of building an underground repository for high-level nuclear waste.

The interim report, released last week by MITI's committee on atomic energy, claims the cost of underground disposal to be eight times more expensive than in France and 13 times more than in Britain. MITI attributes the high estimated cost to extra work required to overcome the problem of high groundwater levels in Japan.

The cost of deep underground disposal in Japan is estimated to be $¥ 2.7$ million (US\$22,460) per cubic metre. According to the report, disposing of 15,000 tonnes of nuclear waste - an average amount produced from dismantling a light-water reactor — could cost $¥ 19.2$ billion.

Given the geological constraints, the construction of the repository would require detailed planning. This would include protective measures against earthquakes to minimize the risk of radioactive material leaching into groundwater.

With a nuclear waste reprocessing facility currently under construction in Rokkasho village, Aomori Prefecture, the government is planning to dispose of nuclear waste in a deep underground repository which it hopes to build between 2030 and 2040 (see Nature 379, 478; 1996).

Japan Nuclear Fuel Cycle Development Organization (JNC), formerly the Power Nuclear Fuel Development Corporation, which plays a central role in investigating the feasibility of deep disposal, is expected to prepare a progress report on nuclear waste disposal by the end of this year.

Based on this report, the government will evaluate the technological reliability of deep disposal by next year, when it plans to establish an agency to carry out the project.

JNC is investigating the 'multi-barrier' system, consisting of engineered barriers (such as vitrified waste and buffer material) and the natural barrier provided by geological formations, as the main model for the planned repository.

But the location of the underground facility remains undecided. And the expense of the programme is likely to become an additional problem, particularly with large cost overruns and delays in the construction of the reprocessing facility.

While MITI is exploring the possibility of extending the operating period of existing nuclear reactors, JNC is planning a more economical model for the repository, for example by relaxing some of the regulations governing its construction.

Meanwhile, the Atomic Energy Commission, which advises the prime minister, has set up a committee to study ways of reducing the production of highlevel nuclear waste.

Three research institutes, including JNC and Japan Atomic Energy Research Institute (JAERI), are developing a technology to stabilize high-level radioactive waste by using fast-breeder reactors and high-energy accelerators.

According to JAERI, such technology could reduce the production of high-level waste by up to 30 per cent, opening up the possibility of keeping such waste "above the ground".

Asako Saegusa 